\title{
The Design of Character Education in the Elementary School at the Coastal of Padang City
}

\author{
Serli Retno Sari, Isnarmi \\ \{Sherly.rsari@yahoo.com $\left.{ }^{1}\right\}$ \\ Department of Civic Education, Faculty of Social Sciences, Universitas Negeri Padang, Padang, \\ Indonesia $^{1}$
}

\begin{abstract}
This paper discusses the design of character education in the elementary school at the coastal of Padang city (Studies in the elementary school 19 Air Tawar Barat and elementary school 06 Pasir Jambak Padang City). As a formal education institution, elementary school 19 Air Tawar Barat and elementary school 06 Pasir Jambak play a role in the formation of the nation's character. Although elementary school 19 Air Tawar Barat and elementary school 06 Pasir Jambak are two schools with different accreditations, elementary school 19 Air Tawar Barat is accredited A while elementary school 06 Pasir Jamba is accredited B, but both schools have students with backgrounds and parents who are not far different, dominated by parents as fishermen and lower middle class economic conditions. The method used is Research and Development ( $\mathrm{R} \&$ D) which gave birth to a hypothetical model in the form of character education design. The resulting character education design is called SEMANGAT which stands for Syukur, Energik, Motivasi, Aktif, Nyaman, Gigih, Asyik, Terarah. SEMANGAT character education design is a solution that can overcome various problems for coastal elementary schools in shaping religious, nationalist, integrity, mutual cooperation and independent character in students..
\end{abstract}

Keywords: Educational Design, Character Education, Coastal Elementary School.

\section{Introduction}

The erosion of noble values is a problem facing the Indonesian people today. The rise of juvenile delinquency cases, violence, corruption and sexual harassment is an indication of the moral degradation of the Indonesian people[1]. Moral degradation that is increasingly dissolving will threaten the integrity of the nation[2][3]. This shows that the importance of character education is done as a solution to restore and strengthen the noble values of the Indonesian nation which is starting to fade.

Coastal communities are communities that need special attention in children's character education. In general, coastal communities in Indonesia have the same problems, namely low levels of education, and inadequate socio-economic life [4]. The low background of parental education on coastal communities causes a lack of parental knowledge of child development and the inability of parents to become a positive example in cultivating good behavior towards their children.

From economic factors, coastal communities generally work as fishermen and depend on the utilization of marine products[5]. In the city of Padang, the fishing community is the worst 
level of poverty[6]. This is seen from the low income of the community, poor housing, lack of skills and low levels of community education.

Schools are one of the institutions that play a role in character building. Khourysuggests that schools become a place for students to develop their own potential and form identity[7]. Freeks adds that schools influence the formation and character development of students[8]. In the implementation of character education must be supported by a learning environment that is capable of giving birth to students' self-confidence with the values of goodness that is instilled in them[9][10]. Diggs \&Akos states that there is a positive relationship between character education and individual achievement, both in the academic field and in social life[11].

Elementary school 19 Air Tawar Barat and elementary school 06 Pasir Jambak are two elementary schools located on the Coastal of Padang City. Elementary school 19 Air Tawar Barat has temporary A accreditation elementary school 06 Pasir Jambak has B accreditation. Nonetheless, both of these schools have student characteristics that are not much different. Based on observations made by researchers in April 2017, it can be seen that most students in both schools speak tend to be rude. Still breaking the rules like being late, not making homework, and dressing not according to the rules. Both schools have students with a background of parents of some fishermen and earn an average of Rp. 500,000 to Rp. $1,000,000 /$ month.

Based on the results of previous research conducted by Murniyetti andEngkizar, it can be seen that the implementation of effective character education in elementary schools in the superior category in the city of Padang can be done through teaching materials, through school regulations, with various student competitions, through national commemoration, worship practices and spiritual guidance, along with various extracurricular activities[12]. Then previous research conducted by Aisyah, Emosda, \&Suratno concluded that the implementation of character education at Elementary school IT Nurulllmi Jambi city starts from the planning contained in the learning tool, its implementation is integrated in every subject, extracurricular activities that contain noble values and adequate school facilities[13]. Furthermore, from the results of research conducted by Alfiah stated that the application of character education at the Pekanbaru City Islamic Boarding School has been in a good category but is still within the limitations of school facilities and lack of examples given by the teacher[14]. However, so far there has been little research on how character education in coastal primary schools. Therefore the author feels interested in doing research in this matter.

Based on the explanation above, the writer would like to know how character education in elementary schools in coastal areas study Elementary school 19 Air Tawar Barat and elementary school 06 Pasir Jambak Padang city and to find out what kind of learning design is suitable to be applied in order to support character education in Elementary school 19 Air Tawar Barat and elementary school 06 Pasir Jambak, Padang city .

\section{Method}

This research is a Research and Development (R\&D). According to Bock, Research and Development $(\mathrm{R} \& \mathrm{D})$ is a process to acquire new knowledge and then apply it to create a new invention or device[15].The aim of $\mathrm{R} \& \mathrm{D}$ research is the development of characteristics of research subjects within a certain period of time. The success of Research and 
Development is the discovery of proven solutions that are able to overcome existing constraints [16].

The implementation of this study uses a development model according to Sugiyono which is modified in accordance with research needs. The stages can be described as follows:

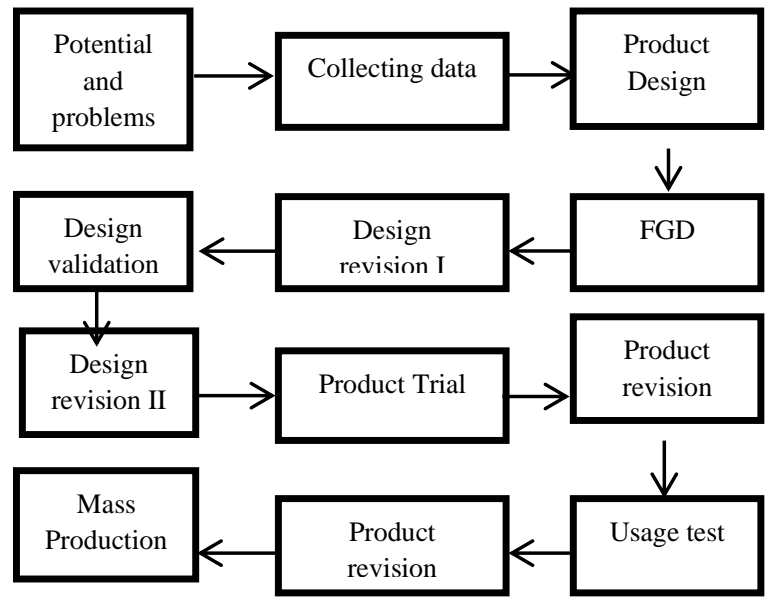

Fig.1. Stages of the R \& D model according to Sugiyono modified with the Prasetyo model.

In this study, the following stages will be carried out:

\subsection{Potential and Problems}

The main activity at this stage is to identify the gaps or problems that will be studied and the potential that can be developed in providing solutions to these problems[17].This aims to find out whether the problems found need a solution in the form of making a new learning design. At this stage researchers will conduct observations, interviews and documentation.

\subsection{Gathering Information}

Activities carried out included direct observation in the field, interviews, documentation and questionnaire filling. The information needed is related to teacher profiles, student profiles and infrastructure.

\section{Teacher Profile}

At this stage, the activities carried out are filling out questionnaires with three main aspects, namely:

FormativeTeacher Experience, including;teacher gender, origin of birth, and tribe.

Teacher Training Experience, including;teacher education level, professional training experience, and job experience

Teacher Properties, including; teacher's attitude towards his profession, teacher's attitude towards students, teacher's intelligence, ability to manage learning and mastery of teaching materials. 


\section{Student profile}

For this stage the aspects that need to be analyzed are:

Pupil Formative Experiences, including;gender, place of birth, place of residence, level of education of parents and socio-economic level of students.

Pupil Properties, includes; basic abilities, knowledge and attitudes of students.

\section{Facilities and infrastructure}

At this stage researchers will conduct direct observations related to the completeness of school facilities and infrastructure that support the learning process. The complete facilities and infrastructure that will be identified include:

Means, including;learning tools (printed books, modules, etc.) and learning media (audio, visual and audio visual)

Infrastructure, including;Classrooms, libraries or reading rooms, prayer rooms, canteens, sports fields, toilets, etc.

\subsection{Product Design}

This activity is systematic starting from determining learning goals, making learning activities design, making learning device designs and determining the learning outcome evaluation tools that will be used.

The steps taken at this stage are:

1 Study the problem and find a solution based on the results of the analysis

2 Formulate learning objectives

3 Design teaching and learning activities (learning strategies)

4 Determine teaching materials

5 Determine learning media

6 Determine learning evaluation tools

\subsection{Focus Group Discussion}

After making the product design, then an FGD was held with experts and practitioners to get advice and input regarding the design.

\subsection{Design Revision I}

The design plan was then revised according to suggestions and input from experts and practitioners during the FGD.

\subsection{Design Validation}

The next activity was validation conducted by a team of expert validators for later revision.

\subsection{Design Revision II}

The design that has been validated by the expert team is then revised.This revision will result in draft II to be piloted at an early stage in the field. 


\subsection{Product Trial}

Activities at this stage are collecting data through filling out questionnaires related to the products made. Product trials aim to find out the weaknesses and shortcomings of the products made.

\subsection{Product Revision}

After testing the product, the data is then analyzed and the product is revised according to the results of the analysis.

\subsection{Usage Test}

At this stage, the design made is used in the learning process.

\subsection{Product Revision}

Weaknesses and shortcomings found during the usage trial were then revised to produce a better product.

\subsection{Mass Production}

The activity at this stage is the publication of the final results of the learning design that has been developed through the validation, revision and trial processes.

The implementation of this research is limited to the stage of design revision II . The learning design that is made is then carried out an FGD with experts and practitioners to get advice and input. The draft was then revised according to suggestions and input to be further validated by a team of experts. The validated design was then revised to get a new concept of character education design on paper. The draft is in the form of models, methods, media and teaching materials needed to overcome the character problems in Elementary school 19 Air Tawar Barat and elementary school 06 Pasir Jambak Padang City. In the end this research will produce a hypothetical model on the design of character education that can be applied in coastal elementary schools.

\section{Result And Discussion}

Elementary school 19 Air Tawar Barat and elementary school 06 Pasir Jambak Padang City are two elementary schools located on the coast of Padang City. Elementary school 19 Air Tawar Barat is an A-accredited school located atPatenggangan Street, Air Tawar Barat Village, Padang Utara Sub-District, Padang City.

According to the research done on from April to September 2018, it is known that at Elementary school 19 Air Tawar Barat most of the students are still in violation of discipline. Such as not making homework, dressing not according to the rules, and often late. In upholding the discipline of teachers at Elementary school 19 Air Tawar Barat applies a reward and punishment system . Like giving praise to students who obey the rules in front of their friends, and punish students who break the rules. However, this is still not 
successful. Based on the results of an interview with Ms. Yuliansah, the Head of Elementary school 19 Air Tawar Barat on September 26, 2018 stated that students at Elementary school 19 Air Tawar Barat on a daily basis tend to speak disrespectfully. This is due to lack of parental attention to their children. Even students who came to school were found dressed in non-compliant rules, such as wearing red and white clothes on Friday, and many of the students dressed poorly and dirty.

From observations that researchers did on September 27, 2018, there were several students who spoke harshly with their peers even to the teacher. However, the teachers at Elementary school 19 Air Tawar Barat remain gentle in facing their students. Most of the parents of students working as fishermen is from 143 students as many as $73 \%$ of parents of students work as fishermen. As many as $15 \%$ work as laborers, $5 \%$ as traders, $2 \%$ as drivers, $2 \%$ as civil servants and 3\% as other professionals. Meanwhile, when viewed from the parents' income, as many as $43 \%$ of parents ofElementary school 19 Air Tawar Barat students have income below Rp. 1,000,000, as much as $18 \%$ have an income of Rp. 1,000,000, as much as $27 \%$ earn between Rp. 1,000,000 - Rp. 2000,000, the rest earn more than Rp. 2,000,000.

Meanwhile elementary school 06 Pasir Jambak is a basic school with B accreditation which is also located on the coast of Padang precisely in the village of Pasir Nan Tigo, Koto Tangah District, Padang City. Based on the results of observations made on April 27, 2018 it was known that from 137 students, 58.4\% of parents of students were fishermen or as many as 80 people. With the income of parents, the majority is Rp. 500,000, / month, which is about $78.8 \%$ of the total students. The low income of parents and jobs dominated by fishermen are assumed to affect the process of character building in children.

As a formal education institution, Elementary school 19 Air Tawar Barat and elementary school 06 Pasir Jambak play a role in the formation of the nation's character. Although Elementary school 19 Air Tawar Barat and elementary school 06 Pasir Jambak are two schools with different accreditations, Elementary school 19 Air Tawar Barat is accredited A while elementary school 06 Pasir Jambak is accredited B, but both schools have students with parents' character and background who are not far away different. The environmental conditions of the family and the community who are still classified as low educated and the lack of school facilities will be a challenge for the Elementary school 19 Air Tawar Barat and elementary school 06 Pasir Jambak in character education for students.

Analyzed from various aspects regarding character education at Elementary school 19 Air Tawar Barat and elementary school 06 Pasir Jambak, both schools have carried out character education programs that are guided by the policies of the Ministry of Education and Culture. When viewed from the competence and attitudes of teachers, both at Elementary school 19 Air Tawar Barat and elementary school 06 Pasir Jambak, both have teachers who are competent and have a positive attitude towards their profession. The teacher always gives good examples to students both inside and outside the classroom. In terms of facilities and infrastructure available, it is also sufficient but still in the process of habituation to students so that they can use it properly and correctly. Besides that, in the learning process there are still many students who are actively directed or in other words like to disturb friends. However, the implementation of character education at Elementary school 19 Air Tawar Barat and elementary school 06 Pasir Jambak still needs to be innovated because there are still many problems regarding the character of students found.

There are many forms of educational design that can be used as references in the learning process. However, based on the results of the analysis of research findings, researchers offer an educational design that can improve students' character. The character education design that the researcher named SEMANGAT. The SEMANGAT character education design is 
an abbreviation of Syukur, Energik, Motivasi, Aktif, Nyaman, Gigih, Asyik, and Terarah. According to the Big Indonesian Dictionary (KBBI) the word SEMANGAT means meaningful, passionate, energetic and ready to fight. This word is expected to become a spirit in implementing character education later. Character education with the SEMANGAT model is preceded by the word syukur. Starting from remembering God and thanking for all the pleasure. Then gratitude is the beginning of the spirit of struggle for students. Furthermore energik has the full meaning of energy. So students don't complain quickly and don't give up quickly while studying. Next is motivasi (full of motivation) which means there is a strong urge to learn both from within the student and given by the teacher. The fourth is aktif which means students are able to position themselves as subjects or objects in education. Furthermore, nyaman, in this case in the implementation of education students are strived to be as comfortable as possible so that there is no compulsion in learning. Next gigih which means there is tenacity in trying in this case learning in students. The seventh is asyik which means that every process that students pass through during the learning process is a fun process. And the last one is terarah with the intention of all the series of activities that have been passed are well organized according to the purpose of education. By implementing the SEMANGAT model character education, students are expected to be able to follow the learning process well and have religious, nationalist, integrity, mutual cooperation and independent character .

\section{Conclusions}

Based on the discussion above, it can be concluded that at Elementary school 19 Air Tawar Barat and elementary school 06 Pasir Jambak a character education program has been carried out, but so far there are still obstacles to the formation of good character in students. Such as difficulties in fostering students to study in an orderly manner without disturbing their friends.

In addressing various problems of character education at Elementary school 19 Air Tawar Barat and elementary school 06 Pasir Jambak, researchers offered character education design innovations called SEMANGAT. SEMANGAT character education design stands for Syukur, Energik, Motivasi, Aktif, Nyaman, Gigih, Asyik, and Terarah. According to the Big Indonesian Dictionary the word SEMANGAT means meaningful, passionate, energetic and ready to fight. This word is expected to be a spirit in the implementation of character education. By implementing the SEMANGAT model character education, students are expected to be able to follow the learning process well and have religious, nationalist, integrity, mutual cooperation and independent character.

\section{References}

[1] A. Rahim Saidek, R. Islami, and Abdoludin, "Character Issues: Reality Character Problems and Solutions through Education in Indonesia,” J. Educ. Pract., vol. 7, no. 17, pp. 158-165, 2016.

[2] Yapandi, "Life Skills Based In Nation Building Character Value Tauhidullah," J. Educ. Pract., vol. 6 , no. 12, pp. 209-223, 2015.

[3] Mohammed Chowdhury, "Emphasizing Morals , Values , Ethics , And Character Education In Science Education And Science Teaching," Malaysian Online J. Educ. Sci., vol. 4, no. 2, pp. 1-16, 2016. 
[4] A. Masri, "Pendidikan Anak Nelayan Pesisir Pantai Donggala," Asian J. Environ. Hist. Herit., vol. 1, no. September, pp. 223-227, 2017.

[5] M. Mislia, A. Mahmud, and D. Manda, "The Implementation of Character Education through Scout Activities," Int. Educ. Stud., vol. 9, no. 6, p. 130, 2016.

[6] Akmal, "Pemenuhan Hak Ekonomi Sosial dan Budaya ( EKOSOB ) Bagi Masyarakat Nelayan di Kota Padang,” DEMOKRASI, vol. X, no. 2, pp. 103-122, 2011.

[7] R. Khoury, "Character Education as a Bridge from Elementary to Middle School: A Case Study of Effective Practices and Processes Ruba Khoury," vol. 8, no. 2, pp. 49-67, 2017.

[8] F. E. Freeks, "The influence of role-players on the character-development and character-building of South African college students," South African J. Educ., vol. 35, no. 3, pp. 1-13, 2015.

[9] G. M. Almerico, "Building character through literacy with children's literature," Res. High. Educ. J., vol. 26, pp. 1-13, 2014.

[10] M. Ülger, S. Yiğittir, and O. Ercan, "Secondary School Teachers' Beliefs on Character Education Competency," Procedia - Soc. Behav. Sci., vol. 131, no. 4310, pp. 442-449, 2014.

[11] C. Diggs and P. Akos, "The promise of character education in middle school: A meta-analysis," Middle Grades Rev., vol. 2, no. 2, pp. 1-19, 2016.

[12] dan F. A. Murniyetti, Engkizar, "Pola Pelaksanaan Pendidikan Karakter terhadap Siswa Sekolah Dasar,” Pendidik. Karakter, vol. VI, no. 2, pp. 156-166, 2016.

[13] N. Aisyah, Emosda, and Suratno, "Implementasi Pendidikan Karakter di SDIT Nurul Ilmi Kota Jambi," Tekno-Pedagogi, vol. 5, no. 1, pp. 50-63, 2015.

[14] Alfiah, "Problematika Penerapan Pendidikan Karakter di Pondok Pesantren Kota Pekanbaru," POTENSIA J. Kependidikan Islam, vol. 2, no. 1, pp. 105-132, 2016.

[15] P. Bock, "Getting it right: R\&D Methods for Science and Engineering." p. 406, 2001.

[16] L. M. Wingate, "Project Management for Research and Development :" pp. 0-4, 2015.

[17] R. M. Branch, "Instructional Design : The ADDIE Approach.” pp. 1-5, 2013. 